\title{
Ideología y parentesco: bases de la actuación política del primer Duque de Nájera a comienzos del siglo XVI
}

\author{
Rosa M. ${ }^{a}$ Montero Tejada
}

\section{INTRODUCCIÓN}

Como es bien sabido, a la muerte de Isabel la Católica (26 de noviembre de 1504) se abrió en Castilla un periodo de crisis política consecuencia del problema sucesorio que el estado mental de la heredera planteaba, porque si se demostraba su incapacidad para gobernar, surgía la disyuntiva de quien asumiria el gobierno, su marido o su padre '. La Reina en su testamento, otorgado el 12 de octubre de 1504, habia designado a Fernando gobernador en Castilla mientras Juana, heredera del reino, estuviese en Flandes, o si no queria hacerse cargo de sus funciones, hasta que Carlos, su primogénito, cumpliese 20 años ${ }^{2}$. Nada más morir Isabel, se proclamó a Juana reina, y cumpliendo con la voluntad testamentaria de la fallecida, asumió la gobernación de Castilla Fernando, quien inmediatamente convocó a las Cortes para que aprobasen dicho esquema politico. Éstas se reunieron en Toro el año de 1505. En la asamblea se declaró la incapacidad de Juana para gobernar, y se aprobó que por derecho correspondia a Fernando el gobierno de Castilla, aunque también se puso de manifiesto la ruptura de la mayor parte de la nobleza con el monarca por su público absentismo a la reunión ${ }^{3}$. La oposición nobiliaria

Pérez, Joseph, La revolución de las Comunidades de Castilla. (1520-1521). Madrid 1978, pág. 74

"Ladero Quesada, Miguel Ángel, Los Reyes Católicos: La Corona y la Unidad de España. Valencia 1989, pág. 291.

${ }^{3}$ Carretero Zamora, Juan Manuel. Cortes, monarquia, ciudades. Las Cortes de Castilla a comienzos de la época moderna (1476-1515). Madrid 1988, pág. 203. 
a que Fernando se hiciese cargo de la gobernación sumió a Castilla en una gran inestabilidad politica.

En el transcurso de esta critica etapa, la nobleza volvió a jugar una baza politica importante, adoptó unos modelos de comportamiento similares a los que había desarrollado antes de la llegada al trono de los Reyes Católicos, y recurrió de nuevo a diversos alegatos políticos para justificar su actuación ${ }^{4}$. Uno de los miembros de la alta nobleza que tuvo un destacado papel en los sucesos que se desarrollaron durante esos años fue Pedro Manrique, I Duque de Nájera, que llegaria a ser la principal cabeza del bando nobiliario antifernandino ${ }^{5}$. Durante casi dos años Pedro Manrique intentó evitar que Fernando tuviese el gobierno de Castilla. Primero lo hizo como destacado partidario de Felipe el Hermoso, con quien mantuvo, antes de su venida a Castilla una intensa correspondencia ${ }^{6}$. En sus cartas el Archiduque prometía siempre recompensar a Pedro Manrique sus servicios, como lo prueba que ya en 1505 hiciese merced del título de Capitán de armas a Álvaro Manrique ', hijo bastardo del Duque, y a él de las alcabalas de la Merindad de Nájera que le habian sido embargadas por Isabel la Católica ${ }^{8}$. Después de la muerte de Felipe el Hermoso, tras su breve reinado, siguió oponiéndose a Fernando como fiel "defensor" de la sucesión de Carlos I, y adicto seguidor del Emperador Maximiliano.

Para defender su causa politica, Pedro Manrique utilizó todos los recursos a su alcance. No dudó en reunir el mayor número de tropas po-

${ }^{4}$ Los conflictivos primeros años del siglo xvı, sobre todo en lo que a la actuación política nobiliaria se refiere, no han recibido aún por parte de la historiografia reciente - a excepción de ciertas obras generales o de otras que tratan el periodo tangencialmente- un tratamiento monográfico y exhaustivo, por tratarse quizá de una etapa bisagra entre los tiempos medievales y modernos. Un trabajo útil aunque muy general es el de CEPEDA ADAN, José. "La monarquia y la nobieza española a comienzos del Estado Moderno", Arbor, 35. Madrid 1967. Son muy provechosas las aportaciones que hizo Fernandez Álvarez, Manuel, en "La Crisis del Nuevo Estado (1504-1516)", para "La España de los Reyes Católicos (1474-1516)", en la Historia de España, dirigida por Ramón Menéndez Pidal, t. XVII. Madrid 1978, págs. 645 y ss., y las referencias que a esos años hacen las obras de Perez, Joseph, ob. cit., y de Haliczer, Stephen, The Comuneros of Castile. The forging of a Revolution, 1475-1521. Madison 1981.

De él dice ZuRita, Jerónimo de, cel que mostrava mayor descontentamiento deste nuevo govierno, y el que mas le abominava, y contradecia en publico y en secreto era el Duque de Nájera, y, el que más se declarava que lo avia de resistir". Los Cinco Libros Postreros de la Historia de Fernando el Católico. Zaragoza 1680, Libro VI, pág. 77.

- Véase Colección de Documentos Inéditos para la Historia de España, (en adelante CODOIN). t. VIII, págs. 280-281, 298, 316.

Por su Real Cédula dada en Bruselas el 1 de agosto de 1505. Archivo de los Duques de Medinaceli. legajo 246, n. 1. Documento citado por GonzÁlez. Moreno, Joaquin, Historia e investigación en el Archivo de Medinaceli. Sevilla 1979.

* Zurita, Jerónimo de, Los Cinco Libros... Libro VI, págs. 13 y 14 
sibles, por lo que "hizo llamar a los de Hamusco, y Bezerril, y los vasallos del Conde de Paredes, y la gente de Dueñas, y del Marqués de Aguilar, aunque le caía lejos, y a todos sus amigos y deudos", e incluso llegó a armar a "çiento y treirita labradores como soldados a la suiça» " También envió, en los primeros meses de 1507, cartas a Álava, Guipúzcoa, la Rioja ${ }^{10}$, Santander y San Vicente ${ }^{11}$ para que siguiesen su opinión y no abonasen las rentas reales. Lo mismo escribió a las ciudades de úbeda y Baeza donde era corregidor su sobrino Antonio Manrique. El Duque continuó oponiéndose a Fernando incluso cuando éste regresó a Castilla en agosto de 1507 , y se negó a comparecer en la Corte ${ }^{12}$ para justificar las más graves acusaciones que el monarca tenia contra él: tomar fortalezas de la Corona Real ${ }^{13}$, nombre y voz de "visorrey", resistir a la jus-

${ }^{9}$ Ibidem. Libro VII. pág. 119. De esta afirmación se desprende que el Duque debia tener cierta confederación con el Conde Buendia, que era el señor de Dueñas, y encomienda sobre la villa de Becerril.

10 Ibidem, Libro VII, pág. 108

"En la villa de Laredo, ante el Corregidor Pedro de Mendoza fue llevado un hombre de Amusco, lugar de Pedro Manrique. Duque de Nájera, quien fue interrogado sobre las cartas que llevaba del mencionado Duque. En concreto se le preguntó si éste había enviado otras anteriormente a la villa de Santander, a lo que el individuo respondió de modo afirmativo, añadiendo que también habia llevado cartas similares a la villa de San Vicente hacia mes y medio. Respecto al contenido cuenta que oyó decir al Duque que uembyaba embaraçar las alcavalas de la dicha villa e que las retoviesen en sy e non acodiesen con ellas sy no byesen firma de la Reyna nuestra Señora". Otro testigo relata que las cartas ahora presentadas tenian la siguiente información: "que no debian pagar ningunos maravedies de las rentas a ninguna persona sin ver cedula firmada de la Reyna nuestra señora, e que asy mismo abya oydo desir que abian dicho los regidores que dixese al duque de palabra como tenyan en mucho lo que les embyaba a desir e tenyan en el un grand capytan..." Otros testigos dan versiones similares. Archivo General de Simancas (en adelante AGS). Cámara de Castilla. Personas. Legajo 19. 1507, marzo, 7. Laredo. Por una carta del corregidor Pedro de Mendoza dirigida a la Reina ese mismo año, sabemos que ésta le habia ordenado por su provisión dada en Palencia, el 28 de febrero, que cualquier mensajero que llevase cartas de "grandes o cavalleros", para las Cuatro Villas o una de ellas que no fuesen cumplideras a su servicio fuese detenido, lo que asi hizo él con un mensajero del Duque de Nájera. AGS. Cámara de Castilla. Personas, legajo 19.

12 Bernaldez, Andrés, narra como el monarca a su regreso a Castilla ufue muy bien recibido y aunque á muchos pesó de su vuelta, ninguno lo osó mostrar, salvo el Duque de Nájera, atreviéndose a su edad de mas de sesenta e cinco años que habia, al qual el Rey envió á llamar y no quiso venir; y le envió decir que si no queria él que él gobernase a Castilla, que la gobernase él; é él le dijo que lo dejase en su tierra en su vejez, reposar ya e nunca quiso venir a la Corte", Historia de los Reyes Católicos. BAE, t. 70. Madrid 1953. pág. 731. De modo similar cuenta ZuRita, Jerónimo de, que cuando el monarca le solicitó que acudiese a la Corte él respondió: «que le dejasen descansar en su casa, que era viejo, y se hallava cansado de servir, que no era para Corte, ni aquella Corte para él». Los Cinco Libros..., Libro VIII, pág. 147.

${ }^{13}$ Como fue el caso de la de Burgos que tuvo que ser sitiada y tomada por el Conde Pedro Navarro. El duque de Nájera se había encargado de su defensa por expreso deseo de don Juan Manuel, señor de Belmonte, que antes de huir de Castilla, ante el inminente 
ticia, impedir el cobro de las rentas de la Corona, etc. ${ }^{14}$. Ante la actitud rebelde de Pedro Manrique ${ }^{15}$, Fernando le ordenó que despidiese toda la gente de armas y entregase sus fortalezas, primero a Fernán Duque de Estrada, su Maestresala, y después, ante las dilaciones del Duque en cumplir el mandato regio, a su Alcalde de Casa y Corte, Hernán Gómez de Herrera, a quien el monarca habia enviado a Nájera. El Rey hizo también pregonar que cualquier persona que tuviese en su tierra a don Álvaro Manrique, hijo del Duque, a don Juan y don Alonso de Arellano, o al Alcalde Mayor de Nájera, algunos de sus principales colaboradores, los entregase, bajo pena de perder la ciudad o villa donde estuviesen recogidos.

Dispuesto a resistir por las armas Pedro Manrique fortificó su ciudad de Nájera ${ }^{16}$ y mandó a sus moradores que obedeciesen al Conde de Treviño, su hijo, mientras él estuviese fuera de Castilla ${ }^{17}$, pues pensó pasarse a Portugal ${ }^{18}$. También fortaleció todos sus otros castillos "y juntó la mas gente que pudo en Nájera, y de su bando, y llamó a sus amigos los vizcainos del bando oñecino, los quales juntaron para venir en su favor fasta tres mil hombres" ${ }^{19}$. Avisado de todo ello, Fernando tomó la última resolución: mandó «a los gamboinos ques bando contrario, que no les dejasen pasar a se juntar con el Duque de Nájera. Los gamboinos cumplieron lo que el Rey les mandó y tomaron el paso a los oñecinos, y

regreso del monarca le había encomendado que protegiese sus intereses. PADILLA, Lorenzo de, Crónica de Felipe el Hermoso. CODOIN, VIII. Madrid 1846, págs. 160-161.

14 Según una carta del rey dada en Arcos, el 23 de julio de 1507 que transcribe ZuritA, Jerónimo de, en Los Cinco Libros..., Libro VIII, pág. 146

${ }^{15}$ Que incluso exigió al monarca «que le embiase seguro si queria que fuese a él. Y como el rey viese la gran osadia del Duque, le envió deçir si solian los grandes señores demandar seguros a sus reyes, porque aunque él por su voluntad ubiese dexado el reino de Castilla, pero que le tenia agora enteramente el derecho de reinar como solia. Lo qual como oyese el Duque, todavia estuvo pertinaz en no venir a su llamada". Santa Cruz, Alonso de, Crónica de los Reyes Católicos. Edición de Juan de Mata Carriazo. Sevilla 1951, pág. 99.

${ }^{16}$ “... el Duque se forticava a prissa en Najara, y mandava hazer baluarte con tierra y rama, y se talaron los falzes y huertas que avia en el campo, y se derribaron muchas casas para poder ofender a los que pusiessen cerco contra aquella Ciudad y no tuviesse la gente íuera a donde repararse, y junto todo el concejo para animarlos...", Ibidem, Libro Vill, pág. 147.

Ibidem, Libro VIII, pág. 147

${ }^{18}$ Según Pedro Mártir de Angleria, Andrés del Burgo, embajador del Emperador Maximiliano, alimentaba continuamente las esperanzas sobre la venida a Castilla del Emperador o del Principe Carlos, y prometía recompensas. Epistolario. CODOIN, vols. IX-XII. Madrid 1953-1957, pág. 79. El Duque que confiaba en esta posibilidad, para ganar tiempo solicitó al rey un plazo para pasarse a Portugal, creyendo que en el interim le enviarian tropas y dinero desde Flandes, o vendria a Castilla el Principe Carlos.

19 Padilla, Lorenzo de, Crónica de Felipe el Hermoso, pág. 161 
hubieron batalla y desbarataron a los oñecinos de manera que les fue necesario volverse a sus tierras, y no pudieron socorrer al Duque ${ }^{20}$. Después el monarca ordenó al Conde Pedro Navarro que pasase a Nájera con gente de guerra y las Compañias de las Guardas - unos dos mil soldados-, tomase el Estado del Duque, y a él le prendiese. Según nos dice el cronista Lorenzo de Padilla, el Rey, como sabia que el Duque de Nájera "era muy osado, y ardil y sabio en la guerra, continuamente apercibia al Conde Pedro Navarro que llevase muy en orden su ejército, y no se descuidase de noche de tener mucha guarda porque no le alcanzase alguna trasnochada del Duque" ${ }^{21}$.

Viendo el cariz que tomaban los acontecimientos, algunos nobles intercedieron por Pedro Manrique ante el rey, especialmente el Duque de Alba, por temer la ofensa que se haria a "los de aquel linage que eran tantos y tan principales en Castilla", y "por que aquella casa, ni un señor tan señalado, como era el Duque no se perdiesen». El de Alba "suplicole que se acordase de los servicios que del habia rescebido, y que le diese licencia para hablar al Duque y lo traer a su servicio" ${ }^{22}$. Finalmente, se llegó a un acuerdo, Pedro Manrique debia entregar todas sus fortalezas - aunque se le permitió conservar la de Nájera-al Duque de Alba, quien prestó juramento el 23 de noviembre de 1507 de que él tendria las dichas fortalezas por la Reina y por Fernando, gobernador de los reinos. En los dias siguientes, Hernán Duque de Estrada entregó la fortaleza de Ocón a Diego de Reinoso, la de Navarrete a Pedro Bernal, la de Davalillo a Juan Bernaldo de Quirós, y la de Treviño a Diego de Vargas. También se dieron las de Redecilla, Ribas y Valmaseda ${ }^{23}$.

El Duque de Nájera habia sido derrotado. Pedro Mártir de Angleria cortemporáneo de la época da esta visión:

"La grandeza del alma suele proporcionar $-\mathrm{y}$ es muy justo- gloria a los generales insignes en la guerra, en cambio, al Duque de Nájera parecía acarrearle su perdición. Era obstinado. Le ordenó el Rey que

(b) Ibidem, pág. 162

${ }^{21}$ Ibidem, pág. 162

Ibidem, pág. 163.

Estas son las fortalezas que cita Zurita, Jerónimo de, en Los Cinco Libros.... Libro VIII, pág. 148. Sin embargo, en las nóminas de Tenencias de Fortalezas no aparece la de Ribas. El año de 1511 se libraban a don Fadrique, Duque de Alba, una serie de maravedies por una cédula real dada el 1 de enero de 1510 para el salario y mantenimiento de los alcaides que tienen las tenencias de las fortalezas del Duque de Nájera. Asi, se libran por Navarrete. 164.000 maravedies; por Ocón, 120.000 maravedies; por Treviño, 120.000 maravedies; por Valmaseda, 68.700 maravedies; por Davalillo, 68.700 maravedies y por Redecilla, 68.700 maravedies. Total: 610.140 maravedies. AGS. Contaduria del Sueldo. 2. ${ }^{a}$ Serie. Legajo 375. 
entregase todas las plazas de su patrimonio. Un ejército, mientras tanto, iba de camino para arrasar todo su señorio, de no obedecer esta orden. Sometió el cuello al yugo. El monarca le dejó únicamente la plaza de Nájera, sin levantarle los réditos, y con nuevas guarniciones en su real nombre puso a seguro las fortalezas de aqué| $>{ }^{24}$.

El propio hijo del duque narraba unos años después la dureza de Fernando con su padre, y asi decia como había enviado «mucha gente de armas contra el y mucha artilleria, y hizo que se tratase con sus vasallos que se levantasen contra el como algunos lo hizieron ${ }^{25}$... tomó los juros desta casa que tenya de antiquisymos tiempos poseydos, que mis anteçesores ganaron en serviçios señalados que hicieron a la Corona Real contra los moros, que ge los vendio para pagar la gente que contra el mismo duque enviaba, y le hizo tomar otras muchas sumas de dineros para dar a la gente que contra el y contra mi casa envió» ${ }^{26}$.

Durante el conflictivo proceso politico que brevemente acabamos de referir, ya que en modo alguno se ha pretendido narrar todos los entresijos políticos en los que se vio envuelto el Duque de Nájera, porque su amplitud hubiera desbordado el marco del presente trabajo, colaboraron con Pedro Manrique un gran número de deudos y parientes. En el transcurso de los hechos el Duque recurrió además a diversos argumentos políticos que justificasen su comportamiento. El presente artículo tratará de reconstruir las relaciones de parentesco y los fundamentos ideológicos del Duque, principales bases sobre las que se asentó su actuación politica en los años a los que arriba se ha hecho referencia.

\section{PARENTESCO Y POLITICA}

Para llevar a cabo su objetivo político de impedir que Fernando asumiese el gobierno en Castilla, el Duque de Nájera contó con el apoyo de

${ }^{24}$ Carta escrita en Arcos el 22 de noviembre de 1507. MARTIR DE ANGLeRIA, Pedro, ob. cit. 1. Il. pág. 220 .

${ }^{25}$ El Arzobispo de Toledo, uno de los que Fernando habia nombrado como su lugartenierite en el gobierno mientras estuvo ausente de Castilla, conociendo las entonces malas relaciones entre el Duque de Nájera y su hijo Antonio Manrique, Conde de Treviño, le ofreció ayudarle con tropas y dinero, para que entrase en las villas de su padre y le crease problemas. Zurita, Jerónimo de, Ibidem, Libro VII, pág. 118. Por este motivo puede suponerse que fuera él quien indujo a los vasallos al levantamiento.

" AGS. Diversos de Castilla, legajo 39, n." 32. Memorial de lo que Antón Gallo habia de decir al Rey Carlos I de parte del Duque de Nájera, redactado el 30 de julio de 1516. Este extenso documento sin foliar, ha servido de base para la elaboración de la mayor parte de este trabajo (en adelante se citará Memorial... y su signatura). 
un amplio círculo de familiares, criados y deudos, que formaban su clientela politico-militar. A estos individuos le unian diversos lazos de parentesco real o ficticio, basados los primeros en los vinculos de sangre, y en los de crianza, servicio doméstico o militar, los segundos.

En 1516 Antonio Manrique, II Duque de Nájera, enviaba a Carlos I un Memorial en el que narraba algunos de los sucesos politicos de los años anteriores, especialmente, como su padre habia rechazado la gobernación de Fernando el Católico, tanto antes como después del fallecimiento del Archiduque, opción politica en la que le habian seguido sus deudos y parientes ${ }^{27}$. El Duque increpaba al rey los muchos daños y agravios que por este motivo habian recibido todos ellos, y solicitaba al monarca ciertas mercedes y compensaciones para los implicados. Gracias a esta información se han podido reconstruir algunas de las principales relaciones de parentesco de los Duques que a continuación se exponen, haciendo al mismo tiempo hincapié, por su interés, en las gratificaciones que pedia Antonio Manrique al rey para ellos, y que por su extensión hemos reunido en varios grupos ${ }^{28}$.

En primer lugar estarian las compensaciones que exige para el circulo familiar más cercano que colaboró con el ! Duque, en el que se incluye él mismo, tanto por ser el heredero primogénito de Pedro Manrique, como por haber continuado con la causa politica paterna. Asi solicita para él, que se le confirmen todos sus privilegios, y los capitulos matrimoniales que se hicieron entre su padre y el Duque de Cardona, su suegro ${ }^{29}$; también pide que se le restituyan los juros que le habian sido confiscados y vendidos; que se le envie una cédula para que pueda volver a cobrar las alcabalas de la merindad de Nájera embargadas por Fernando, y finalmente que el monarca le entregue la tenencia de La Guardia, según se

" Ibidem. Dice asi Antonio Manrique: “... Despues del falleçimiento de la Reyna doña Ysabel nuestra señora... el Duque mi padre en gloria sea, acatando la fidelidad que debia, se puso en sostener que la governaçion destos reynos perteneçia al muy alto e muy poderoso señor el rey don Felipe, nuestro señor... por lo quel resçibio muy grandes daños. por quel señor rey de Aragon a esta cabsa embio muchas vezes gentes de armas contra el, y tambien enbio muchos caballeros e personas prinçipales para que por temores o por promesas y mercedes le traxieran a su voluntad y quisyese yr a su corte...".

${ }^{28} \mathrm{Ibidem}$. Dice el Duque en el Memorial: "... Dires a su alteza que le suplico me haga merçed de prober a las personas aqui contenidas de los oficios syguyentes puesto para quien se piden lo tienen tan bien mereçido como es notorio, y han padeçido tantos trabajos despues del fallecimiento del Rey don Felipe nuestro Señor".

29 Los Reyes Católicos habian aprobado y confirmado estos capitulos, que se habian otorgado el 17 de septiembre de 1497, por su cédula dada en Medina del Campo el 23 de septiembre de 1504. Real Academia de la Historia (en adelante RAH). Colección Salazar y Castro, (en adelante Salazar) M-2, fols. 70-80r. pub. por Salazar y Castro, Luis, Pruebas Históricas de la Casa de Lara, (en adelante Pruebas). Madrid 1696, págs. 323-326. 
la habia dado el rey Felipe a su padre, y la de Pamplona. Además le ruega que se pague a la gente de la capitania de don Álvaro Manrique, su hermano, "porque a cabsa de aver probeydo el Rey don Felipe nuestro señor della, el señor rey de Aragón nunca dio lugar que se pagase de las rentas del reyno como las otras, y a la cabsa estan empeñadas muchas cosas desta casa para pagar la dicha capytanya...". Le dice también que en el último servicio que se impuso en el reino, le tocó a sus tierras abonar ciertas cantidades, pero que como sus vasallos están tan fatigados por los recientes daños sufridos, les exima de dicho pago.

Para sus hijos y hermanos, que como familiares directos no es de extrañar que apoyaran la causa de Pedro Manrique, además del hábito de Santiago para su hijo Juan Manrique, solicita expresamente que se entregue la tenencia de los Arcos y las Torres de Logroño a don Juan y don Jorge, sus hermanos, "pues de mas de mereçerlo por ser hijos del Duque mi padre, es vien que sepa su alteza que Logroño esta en la Corona Real porque el Duque la redimio, defendiendola a quyen la tenya y poseya por suya en tyempo del Rey don Enrique, como hizo a Vizcaya y a otras muchas villas y lugares destos reynos". Luego en lineas generales le pide "que en las bacantes que de aqui adelante hubiere se acuerde que el duque mi padre dexo muchos hijos y parientes muy gastados por serbir a su alteza y que yo asy mesmo tengo hijos, y que por ser sus serbidores fasta aqui no se nos ha hecho parte en ninguna cosa que aya bacado, salbo en las malas obras, para que Su alteza de mas de hazernos merçed, descargue su conçiençia en semejantes cosas que estas que de neçesidad se han de dar quando bacan".

En un segundo bloque estarian las peticiones que se refieren a otros parientes, en los que cabe distinguir entre los que pertenecen al linaje Manrique y los que son familiares por vinculos matrimoniales. Entendiendo el término linaje en el sentido amplio que le otorgaban en la época las fuentes literarias -crónicas, memoriales y nobiliarios-, que le definen como el conjunto de descendientes de un mismo antepasado ${ }^{30}$, sorprende el elevado numero de miembros del citado linaje Manrique que aparecen en el memorial, porque su presencia indica una gran cohesión a la hora de seguir una candidatura política. Recientemente se ha apuntado ${ }^{31}$ la necesidad de evitar la simplificación de concebir al linaje

30 Gerbet, Marie Claude, La nobleza en la Corona de Castilla. Sus estructuras sociales en Extremadura (1454-1516). Cáceres 1989, pág. 97

${ }^{31}$ Nos referimos a BecEIRo PITA, Isabel, en su libro realizado con CORDoba de LA LLAVE, Ricardo, Parentesco, poder y mentalidad. La nobleza castellana, siglos xII-xv. Madrid 1990, pág. 309. 
noble como un todo homogéneo en sus opciones politicas, máxime si se tiene en cuenta, que como señaló Marie Claude Gerbet ${ }^{32}$, todo linaje llevaba en si mismo un germen de ruptura al multiplicarse las lineas familiares. A partir de un determinado tamaño la separación era inevitable, y al producirse ésta, las ramas autónomas del mismo tronco familiar gozaban de gran independencia en materia politica ${ }^{33}$.

En lo que a los Manrique se refiere, el linaje habia sufrido a fines del siglo xIV una importante escisión que le habia dividido en dos grandes ramas, una representada entonces por el Adelantado Pedro Manrique, y otra por Garcí Fernández Manrique, Conde de Castañeda. Ambas líneas crecieron autónomamente a lo largo del siglo xv. De la prolifica descendencia del primero surgieron los Condes de Treviño, los Condes de Paredes, los Señores de las Amayuelas, los de Valdezcaray, los de Hito y los de Villazopeque -aunque estas dos últimas lineas se extinguieron por falta de heredero varón-, en virtud de los seis mayorazgos que habia fundado el Adelantado gracias al rico patrimonio acumulado durante años ${ }^{34}$. Por otra parte, de los Condes de Castañeda, habian nacido la importante rama de los Condes de Osorno, y otras secundarias. Todas ellas se multiplicaron con mayor o menor fortuna, lo que causó cierto alejamiento progresivo e irrefutable entre sus componentes, que solo mantuvieron relación en los circulos familiares más próximos. La creciente división en ramas autónomas provocó una policefalia familiar en el linaje que imposibilitaba el nacimiento de una «jefatura politica» única. Por este motivo se observa que los Manrique, durante los conflictivos sucesos politicos que sacudieron Castilla a lo largo del siglo xv, actuaron con gran independencia, y que si al final coincidieron en una opción politica concreta, póngase por caso, el partido de los Reyes Católicos, fue más por criterio propio, que por motivos de acuerdo previo dentro de una política común establecida por un pariente mayor o jefe politico, ya que esta figura no existia en el linaje en esos momentos. No puede negarse, sin embargo, que siempre hubo ciertas presiones de unos familiares a otros para intentar atraer a su parentela a un determinado partido.

Esta tendencia debió cambiar a comienzos del siglo xvi, como se comprueba gracias a la información que nos da Antonio Manrique, ya que el linaje en general estuvo mucho más comprometido politicamente con el I Duque de Nájera, principal cabeza del bando nobiliario antifernandino,

32 Gerbet, Marie Claude, ob. cit., pág. 100

33 Beceiro Pita, Isabel, y Cordoba de la Llave, Ricardo, ob. cit., pág. 309

34 Testamento otorgado en Valladolid el 20 de septiembre de 1440. RAH. Salazar, M-2, fols. 83 a 93. Pub. por Salazar y Castro, Luis, Pruebas, págs. 256-261. 
de lo que a simple vista pudiera pensarse, y se observa su "jefatura política» sobre la mayor parte de la familia. La explicación a este cambio hay que buscarla en la interrelación entre la trayectoria interna del linaje, y la coyuntura politica de finales del xv, es decir, el reinado de los Reyes Católicos. Coincidiendo con la llegada al trono de Isabel y Fernando la policefalia política del linaje empieza a resquebrajarse. En un corto espacio de tiempo desaparecieron algunos de sus miembros más importantes. En 1476 muere el célebre Maestre de Santiago, Rodrigo Manrique, y si bien es cierto que le sucedió su hijo Pedro, II Conde de Paredes, su prematuro fallecimiento en $1481^{35}$ dejó a esta rama aislada y fuera del entorno político durante varios años, al recaer la sucesión en un niño. El resto de los hijos del Maestre, además de ser entonces demasiado jóvenes, no contaban con un patrimonio que les permitiese alcanzar un nivel social y político elevado, por la precaria situación económica en la que les habia dejado su padre. Otro personaje de rica actividad política, Fadrique Manrique, señor de Hito, fallece en 1477 sin sucesor varón que siga su línea ${ }^{36}$.

Gómez Manrique, también destacada figura del linaje, aunque poco afortunada - a pesar de haber sido un gran colaborador de los monarcas, y uno de sus consejeros-, desde su nombramiento como corregidor de Toledo en 1477 sufrió cierto ostracismo político. La muerte de su único hijo varón L.uis Manrique, quebraria su descendencia ${ }^{37}$. Garcí Fernandez Manrique, señor de las Amayuelas, personaje secundario, pero de cierta actividad politica, dividió su patrimonio en dos mayorazgos, uno para su primogénito Bernaldino Manrique, con sus propiedades en Palencia, y otro para İñigo Manrique, con la villa de Frigiliana, en tierras malagueñas ${ }^{38}$. Mientras que el primero tuvo una trayectoria política anodina, el segundo, logró fortalecer su posición socio-económica, gracias a su rica actuación política como Alcaide de la ciudad de Málaga, y a su fiel apego a la Corona. Sus esfuerzos se verian recompensados finalmente, pues sus descendientes llegaron a ser Condes de Frigiliana.

En suma puede decirse que en torno a 1480 solo permanecian pujantes politica y socialmente hablando, los Condes de Castañeda y los Con-

\footnotetext{
35 Salazar y Castro, Luis, ob. cit., t. II, pág. 339.

${ }^{36}$ Falleció aproximadamente entre el 4 y el 7 de marzo, según Calderón Ortega, José Manuel, "El Caso de la encomienda de Azuaga (1465-1478)», Espacio, Tiempo y Forma, Serie 111,1988 , pág. 113.

3i El joven murió hacia 1487. Salazar y Castro, Luis, ob. cit., vol. II, págs. 548-549

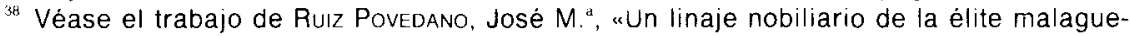
ña: los Manrique", en Las ciudades andaluzas (siglos xlli-xvi). Actas del $V$ coloquio Internacional de historia Medieval de Andalucia. Málaga 1991, págs. 435-452.
} 
des de Treviño que fueron recompensados por los Reyes Católicos con los títulos de Marqueses de Aguilar y Duques de Nájera respectivamente ${ }^{39}$, en premio a sus servicios. También gozaban de cierto prestigio los Condes de Osorno. Durante los años previos y los siguientes a dicha fecha, la pacificación del reino y la instauración de un gobierno estable por Isabel y Fernando acabo con el que habia sido el mecanismo por excelencia de medro politico y económico para la nobleza, la lucha política. El equilibrio político provocó un "status quo" dentro del linaje, la promoción interna desapareció, porque los patrimonios se estabilizaron en un momento en el que el linaje habia alcanzado unas elevadas cotas de reproducción por la fuerte natalidad de sus miembros, de forma que las diferencias socio-económicas se hicieron entonces mucho más acusadas que veinte años antes. La tendencia fue el progresivo empobrecimiento de las ramas secundarias, que entraron en decadencia, situándose en un nivel de nobleza medio, e incluso en algunos casos muy bajo. En esas circunstancias resulta comprensible que el Duque de Nájera, el más rico y poderoso de todos los Manrique, fuera ejerciendo una fuerza centrifuga respecto a los demás miembros de la familia, ya que no tenía rival político ni económico dentro de ella. A partir de entonces empezó a acusarse su jefatura politica, que se plasmó nitidamente en los sucesos de 1505-1507. Al surgimiento de lazos de clientelismo político por las peculiares circunstancias personales de los Manrique y por la coyuntura política y social del momento, se unia el que a pesar del relativo distanciamiento, habia habido siempre cierta conciencia en todos los miembros del linaje de la descendencia común de unos mismos antepasados, cuya linea principal de sucesión estaba representada por los herederos directos del Adelantado Pedro Manrique, entonces su nieto y homónimo el Duque de Nájera, -es decir, "el primogénito de la rama primogénita»— ${ }^{40}$ quien en alguna ocasión se habia definido así mismo como "cabeza de los Manrique».

El Memorial redactado por Antonio Manrique nos ha permitido saber qué miembros del linaje reconocian la "jefatura politica" del Duque de Nájera. Comenzaremos por los personajes más importantes, entre los que cabe destacar al Marqués de Aguilar, entonces Luis Fernández Manrique. Su padre, Garci Fernández Manrique, III Conde de Castañeda, habia acudido en 1506 a La Coruña al recibimiento de Felipe el Hermoso y doña Juana, mostrando su adhesión a los nuevos soberanos. Volvía a Castilla

39 López de Haro, Alonso, Nobiliario genealógico de los Reyes y Titulos de España. Madrid 1622, vol. I, fols. 178 y 306-308.

4u Gerbet, Marie Claude, ob. cit., pág. 98. 
acompañando a los Reyes cuando le sorprendió la muerte en Monterrey (Galicia), en el mes de junio ${ }^{41}$. Su hijo, Luis Fernández Manrique, IV Conde de Castañeda y II Marqués de Aguilar, siguiendo con la orientación política paterna, se adhirió al bando nobiliario que se oponia a la gobernación de Fernando el Católico, porque cuando el Conde de Benavente volvió al servicio de Fernando, «... pidió que se confirmase al Marques de Aguilar el oficio de Canciller que tuvieron su padre y su abuelo, de que también le hizo merçed el rey don Felipe, y concediosele de parte del Rey $"{ }^{42}$. Por tanto cabe afirmar que el Marqués se reintegró pronto a la fidelidad regia, aunque no debió ser un proceso sencillo, pues Antonio Manrique pide en su Memorial que se le recompense por los agravios cometidos contra él. Resulta dificil saber cuáles fueron los motivos que llevaron al Marqués a establecer esta relación politica con el Duque de Nájera, ya que durante los años anteriores habian tenido ciertas diferencias. El duque se habia autotitulado heredero del Condado de Castañeda, porque consideraba que los descendientes de Juan Manrique, II Conde de Castañeda, eran ilegitimos, al haber nacido de su pariente Catalina Enriquez. No sabemos en qué momento abandonó este empeño, pero puede suponerse que existió algún tipo de concordia con el Marqués de Aguilar que fuera la base de esta nueva relación politica.

Otro personaje que aparece mencionado en el Memorial ${ }^{43}$ es Rodrigo Manrique, III Conde de Paredes, quien, según dice Jerónimo de Zurita permaneció en la fidelidad del rey Católico, a pesar de ser su tio el Duque de Nájera, uno de los que más se oponia a la gobernación de este monarca. A principios del año 1507, dice el mencionado autor, que Rodrigo hizo una confederación con el Conde de Tendilla, el Adelantado de Murcia, Pedro Fajardo, el Conde de Cabra y el Marqués de Priego, para guardar el servicio del rey ${ }^{44}$. Sin embargo, el Duque de Nájera le pidió ayuda ese mismo año, pudiendo ser entonces cuando se adhirió a su causa.

El señor de las Amayuelas, Bernaldino Manrique, siguió también la parcialidad del Duque de Nájera, ya que éste había mantenido siempre una cordial relación familiar con su padre Garci Fernández ${ }^{45}$, que continuó teniendo con él. Sin embargo, su hermano Iñigo Manrique, que du-

41 Galindez de Carvajal, Anales breves del Reinado de los Reyes Católicos. BAE. t. 70. Madrid 1953, pág. 555. 133.

${ }^{43}$ Memorial... AGS. Diversos de Castilla. Legajo $39, n .^{\circ} 32$.

${ }^{44}$ Zurita, Jerónimo de, ob. cit., Libro VII, pág. 116.

45 Garci Fernández Manrique actuó como su "Curador" en el otorgamiento de algunos documentos mientras el duque fue menor de edad. Salazar y Castro, Pruebas, pág. 290. 
rante los acontecimientos que nos ocupan era Alcaide de la ciudad de Málaga, se mantuvo fiel a Fernando el Católico y por este motivo a su llegada a Castilla, Felipe le cesó en la alcaldia, que entregó a Alonso de Cárdenas ${ }^{46}$. La temprana muerte del rey impidió a este personaje tomar el cargo, quedándose Iñigo Manrique en él. Su fidelidad al monarca debió ser la causa de las mercedes ${ }^{47}$ que recibió a comienzos de 1508 . Es curioso que sea éste el único personaje de relativa importancia en el linaje que se mantenga al margen de la adhesión politica al duque. La distancia geográfica del resto de sus familiares parece ser la causa de su independencia politica y de la falta de relaciones con sus parientes, no solo ya con el Duque de Nájera, sino con su propio hermano.

Otros individuos que aparecen en el Memorial y que debemos destacar por su estrecha relación con el duque y con los sucesos acontecidos, son los Señores de Valdezcaray, representados entonces por Pedro Manrique, segundo señor de dicha villa, y su hijo Antonio Manrique. Además del parentesco, existía de antaño una gran relación familiar, ya que el primer señor de Valdezcaray, también llamado Pedro, había sido uno de los familiares que habia ayudado al Duque de Nájera durante su minoria de edad, en los pleitos que sostuvo con su madre sobre la administración del patrimonio paterno. Prueba, asimismo, la gran vinculación entre ambos, el que Pedro Manrique hubiese entregado en encomienda su villa de Ezcaray al duque unos años antes, aunque los reyes le habian obligado después a anular dicha encomienda ${ }^{48}$. Por otra parte hay que tener en cuenta que esta familia se vio implicada de lleno en los acontecimientos políticos porque Pedro Manrique estaba casado con Elvira Laso Manuel, hermana de don Juan Manuel, señor de Belmonte, uno de los principales consejeros de Felipe el Hermoso y activo opositor de Fernando. Tanto Pedro como su hijo mayor Antonio apoyaron firmemente dicha causa, recibiendo el último del rey Felipe el Corregimiento de Úbeda ${ }^{49}$ y Baeza. Fernando a su regreso a Castilla castigó duramente a esta familia, ya que

46 Padilla, Lorenzo de. Crónica de Felipe el Hermoso, pág. 148.

4i Cédula de la Reina doña Juana y Fernando, por la que hacen donación ade todos los heredamientos e bienes raices de tierras, e viñas, e morales e huertas, prados de los vecinos del lugar de Frigiliana, tierra de Vèlez-Málaga, que es el Reyno de Granada, que eran cristiano nuevos...". Burgos 1508, febrero, 26. RAH. Colección Salazar, M-7, fols. 15 a 16.

48 AGS. Registro General del Sello. 1498-octubre-9. Valladolid, fol. 84.

${ }^{49}$ Este personaje estuvo muy relacionado con los bandos de la ciudad de Úbeda apoyando a la familia de los Molina frente a los de La Cueva. A dichos hechos hace referencia Pedro Mártir de Angleria en una de sus cartas dirigida al Conde de Tendilla, en la que le dice «que tu eres el primer sobre quien recaen las sospechas de favorecer desde Granada la facción de los Molinnenses, por haber dado hospitalidad a Antonio Manrique. gobernador de Úbeda, que es adversario del Rey Fernando, y se murmura que has entablado con él un pacto secreto". Villorrio de Hornillos, 15 de julio de 1507, ob. cit., t. II, pág. 202. 
Pedro Manrique estuvo apresado durante siete años. No es de extrañar por tanto, que el segundo Duque de Nájera haga unas peticiones especiales para ellos. Asi dice al rey: «que en recompensa de lo que don Antonyo Manrique y su padre han serbido, se acuerde quando obiere de prober de la tenençia de Atiença del dicho Antonyo, para le fazer merçed de le prober della». También solicita que le entregue una "capytania de çien ombres de armas y la escribanya y balança de las Yndias". Además refiere al monarca que ciertás personas habian procurado levantarles los vasallos, y que les habían impedido llevar las alcabalas y tercias de la villa de Anguiano, para cuyo cobro, añade, estos señores se veian obligados a obtener una nueva provisión cada dos años. Antonio Manrique pide para ellos una cédula que les permita recaudar sus rentas libremente.

Otro personaje que aparece mencionado en el Memorial del Duque es Fadrique Manrique ${ }^{50}$, conocido como Mariscal de Zamora. Fadrique pertenecia a una rama secundaria nacida en el tronco de los Condes de Castañeda, porque su padre Juan Manrique, I señor de Fuenteguinaldo, fue hijo del segundo Conde de Castañeda y de Catalina Enríquez. La relación de clientela politica de Fadrique con el I Duque de Nájera debió tener su raiz en el parentesco, al ser su madre, Beatriz Manrique, hermana del mencionado duque. Para él solicita Antonio que se le entregue la tenencia de Zamora, ciudad de la que Fadrique era regidor.

Por último, aparecen también citados en el Memorial, Rodrigo Manrique y sus hermanos. Aunque no sabemos a quiénes se refiere, pues no se especifica ningún otro dato que nos permita ubicarlos en el linaje, hay razones para sospechar que se trata de los hijos del Maestre de Santiago Rodrigo Manrique. La precaria situación económica de estos individuos, a la que ya hicimos referencia, explica su adhesión al Duque de Nájera, ya que debieron ver en él, como pariente poderoso, una vía alternativa para mejorar sus estatus. Resulta curioso que no se mencione en el Memorial a Alonso Manrique, obispo de Badajoz, -también hijo del Maestre--, tanto por su estrecha amistad con el Duque de Nájera, como por haber sido uno de los más fieles seguidores de la causa de Felipe el Hermoso, y miembro destacado de la oposición a Fernando. Alonso, cuando la vuelta del monarca a Castilla fue eminente, decidió partir a Flandes para ponerse al servicio del Principe Carlos. Asi, preparó en secreto su

so Este personaje sirvió unos meses después en la corte de Carlos I, quien pedía el 7 de octubre de 1516 al Cardenal Cisneros que le diera un oficio según su persona. AGS. Secretaria de Estado, leg., 3, fol. 199. Publicado por LoPEz DE Arala, Jerónimo, El Cardenal Cisneros, gobernador del Reino. Madrid 1911, vol. III, pág. 406 
partida, y en la cuaresma de 1508 estaba en el monasterio de Santa Catalina de Montecorban, en la costa de Santander, esperando para ser embarcado, pero fue descubierto y detenido ". Permaneció preso en el castillo de Atienza varios meses, en los que se le intentó procesar sin éxito por falta cie argumentos. Después fue trasladado a lllescas y a Toledo donde estuvo hasta 1509, año en el que el Emperador Maximiliano y Fernando establecieron ciertos acuerdos sobre la gobernación. Con permiso del rey se dirigió entonces a Badajoz, desde donde pasó a Portugal ${ }^{52}$, embarcando en octubre de 1509 en Lisboa hacia Flandes. El que no aparezca mencionado en el Memorial es, por tanto, comprensible, ya que el obispo gozaba de una situación inmejorable como servidor de Carlos 1.

De todo lo expuesto se desprende, que de una forma $u$ otra prácticamente todo el linaje Manrique se vio envuelto en los sucesos de esos años y apoyó la causa política del duque. Tan solo dos personajes importantes Ínigo Manrique, Alcaide de Málaga, y Pedro Manrique, Conde de Osorno permanecieron al margen. Confirma la «jefatura politica" de los Duques de Nájera, el papel protector que adopta el II duque, Antonio Manrique, sobre los citados miembros del linaje en sus peticiones a Carlos 1.

En lo que a los familiares por lazos matrimoniales se refiere encontramos también algunos datos en el Memorial. Asi el duque explica que de Aragón y de Cataluña le habian escrito y enviado sus mensajeros el Duque de Cardona, el Arzobispo de Tarragona, el Conde de Aranda, el Arzobispo de Monreal, y el Gobernador de Cataluña, sus cuñados, además del Conde de Fuentes, el de Velchite y otros caballeros, para que les diera noticias sobre la situación en Castilla. Todos estos señores le hacian saber en sus cartas que estaban con él en lo que al servicio de Carlos tocaba. Antonio Manrique intercede por todos ellos y pide al monarca que les escriba "y les mande en que syrban pues son tales personas y que tanto hazen al caso del seviçio de su alteza", pero hace mención especial de don Antonio, Duque de Cardona, que además de ser su cuñado, estaba casado con su hermana Francisca Manrique ${ }^{53}$. Asi ruega

\footnotetext{
${ }^{51}$ Antonio Manrique narraba también en el memorial que Fernando el Católico habia puesto guardias en los puertos para impedir la salida de Castilla a los que querian irse a servir a Carlos I a Flandes. Memorial... AGS. Diversos de Casilla, legajo 39, n." 32.

5. ZuRita, Jerónimo de, Los Cinco Libros..., Libro VIII, pág. 173-174.

${ }^{53}$ El matrimonio de Fernando de Cardona, entonces Almirante de Aragon, con Francisca Manrique se capituló en Epila el 17 de febrero de 1497, al mismo tiempo que el del II Duque de Nájera con Juana de Cardona. RAH. Salazar. M-2. fols. 70-804. Pub. por Salazar y Castro, Luis, Pruebas, págs. 323-326.
} 
al rey que le haga la merced de darle "el cargo de la capytanya de las cuatro galeras que su alteza tiene en la costa de la mar de Granada, y de la Baylia General de Cataluña que es de fasta 300 ducados de derechos para quando bacare la dicha baylia que la tiene un cavallero biejo".

También solicita al monarca que haga merced a otro de sus cuñados, el Conde de Ayamonte ${ }^{54}$, de una alcaldia mayor de Sevilla. Antonio narra como en esta ciudad hay seis alcaldes mayores, y que cinco son personas de estado, pero el otro que se llama Martín Seron, tiene poco y está privado de la alcaldia por el Cardenal. Le dice que el mencionado Conde de Ayamonte se encargaría de recompensar a Martín por la pérdida del oficio con «tanta cantidad como dio el Marques de Tarifa a don Pedro de Guzmán por otra alcaldia que en el renunçio".

Otros familiares que se citan en el Memorial son Pedro Vélez de Guevara y Pedro de Beaumont. El primero era hijo de Victor Vélez de Guevara, II Conde Oñate, y de Juana Manrique, hermana de Antonio Manrique ${ }^{55}$. El segundo era uno de los hijos de Luis de Beaumont, III Conde de Lerin, y de Brianda Manrique, también hermana del duque ${ }^{56}$. Además de los lazos de parentesco, parece ser que estos señores recibian acostamiento de Antonio Manrique, quien pide para sus dos sobrinos que se les ofrezca en qué servir.

En el último apartado se han reunido las peticiones para los deudos, vasallos y otros servidores, a los que también se les denomina uparientes» en alguna ocasión, y que forman el circulo del parentesco ficticio. Este bloque de demandas es mucho más heterogéneo y las menciones que son varias a lo largo del Memorial, se encuentran, a veces, repetidas y entremezcladas con las referencias a otros familiares directos. Conviene aclarar que aunque son numerosos los "parientes y criados" de los duques que se citan en el Memorial, no están todos, pues por otras fuentes sabemos que la casa ducal de Nájera contaba con otros muchos ca-

${ }^{34}$ Se trata de Francisco de Zúñiga y Guzmán, Conde de Ayamonte y Señor de Lepe, que contrajo matrimonio con Leonor Manrique, una de las hijas del I Duque de Najera y de Guiomar de Castro. SalAzAR Y CAStRo, Luis, Historia Genealógica de la Casa de Lara. Madrid 1693, t. II, pág. 144.

El | Duque de Nájera daba una escritura de dote a su hija Juana, el 13 de junio de 1479, en Salvatierra para efectuar dicho enlace. RAH. Salazar. M-10. fol. 297. Pub. por SA. LAZAR Y CASTRO, Luis, Pruebas, pág. 306.

${ }^{36}$ Este matrimonio se celebró en 1486, según se desprende de la escritura que entregó Brianda Manrique, el 16 de septiembre de dicho año por la que renunciaba a su legitima a cambio de la dote. RAH. Salazar. M-8, fols. 152-152v. Pub. por Salazar y Castro, Luis, Pruebas, pág. 310 . 
balleros y continuos que formaban su clientela ${ }^{57}$, por lo que cabe suponer que los que aqui se recogen debieron ser los que mantenían unos lazos más estrechos con los duques, o que los demás pueden darse por incluidos en la alusión global que hace Antonio Manrique cuando refiere:

"que pues los parientes de esta casa han padecido muchos trabajos y daños, y los criados della, que su alteza se acuerde dellos en el prober de los ofiçios y tenençias y capitanias destos reynos...”.

En la época, como ha señalado M. C. Gerbet, con el término "criado» se designaba a todos aquellos que recibian del señor una remuneración en pago de sus servicios. La palabra criado englobaba distintas funciones, asi como niveles sociales y modos de vida diferentes, desde domésticos, esclavos, o empleados, hasta escuderos y alcaides. Algunos, designados con frecuencia con el término de "continuos", eran alojados, alimentados y vestidos por el señor; otros, vivian independientemente, recibian una remuneración anual fija y una indemnización por dia de servicio efectivo ${ }^{58}$.

Entre las menciones específicas de criados del duque tenemos las siguientes peticiones. Para Alonso Barahona se solicita el oficio de Diputado de Álava. Este personaje fue, según se lee en algún documento, "gobernador en la villa y Condado de Treviño" ${ }^{59}$, y uno de los más fieles servidores del primer Duque de Nájera, quien en prueba de su afecto pedia a su hijo en su testamento que le conservara en sus cargos ${ }^{60}$.

También aparecen mencionados en el Memorial otros dos leales oficiales de los duques, Juan de Salinas y Antón Gallo. Para estos letrados Antonio Manrique pedia que se les confirmasen los 25.000 maravedies de situado que el Rey don Felipe le había dado al primero, y el oficio de escribano que tenia el segundo. Para los licenciados Rodrigo de Alfaro y Xuares que igualmente habian sido servidores de la casa de Nájera, decia el duque que "como su alteza se ha de serbir de otros letrados de oficiios

\footnotetext{
"Según consta en una nómina de "caballeros y continuos del Duque don Pedro", que publicó Salazar y Castro, Luis, Pruebas, págs. 297-298.

${ }^{8}$ Gerbet, Marie Claude, ob. cit., pág. 140.

:9 AGS. Cámara de Castilla, legajo 19. Personas. Firma como testigo en un pleito en Logroño, el 17 de julio de 1512. En opinión de Marie Claude Gerbet, los criados que firman como testigos solian formar parte del séquito personal del señor, al que acompañaban en sus actividades. Eran de condición social elevada, con preferencia escuderos, o detentadores de un cargo importante en la administración señorial, como seria el caso de Alonso de Barahona, ob. cit., pág. 140.

60 Testamento dado en Navarrete el 22 de enero de 1515. RAH. Salazar. M-1, fols. 92-96. Publicado por Salazar y Castro, Luis, Pruebas, págs. 299-304.
} 
en este reyno, le suplico que acordandose delo mucho que han serbido se syrba dellos en los cargos e ofiçios que segund sus letras y personas combiene». Desde el siglo $x V$, según se ha dicho, la progresiva especialización y complejidad de las estructuras administrativas de la casa señorial aumentó la demanda de letrados -licenciados, bachilleres o antiguos escribanos concejiles-, que por sus imprescindibles servicios gozaron de la consideración especial del noble ${ }^{61}$, como debió suceder con los arriba mencionados y los dos primeros Duques de Nájera. Los servidores que Antonio Manrique cita, habian prestado importantes servicios a sus señores, incluso en delicadas misiones de carácter político, como fue el caso de Antón Gallo, a quien el I Duque de Nájera envió a la corte de Felipe el Hermoso, o de Juan de Salinas, en la de Fernando el Católico.

Para el alcaide de Soria, Jorge de Beteta, solicita la "vehedoria de la gente de las guardas» ${ }^{62}$. De él Antonio Manrique dice que una vez que el rey se haya informado «de su persona y abylidad y de lo que ha serbido y mereçe, hallara que es de las mas abyles personas que ay en este reyno para ello y de los que mejor lo mereçen". Este personaje habia sido durante años servidor del I Duque de Nájera, quien incluso en su testamento le habia dejado al cargo de la villa y fortaleza de su villa de San Pedro hasta que se cumpliesen sus últimas voluntades ${ }^{63}$.

En suma, como ha destacado M. C. Gerbet, algunos criados de valia que vivian en las casas de grandes señores, tenian posibilidades de enriquecerse, y de situarse en un nivel social más alto si hacian una buena carrera, que consistia en obtener, gracias a la influencia del señor, cargos, honores y rentas ${ }^{64}$. La autora arriba mencionada señala que la carrera de un criado, primeramente privada, en ocasiones desembocaba en una carrera estatal al servicio del rey ${ }^{65}$, afirmación que se cumple plenamente en los ejemplos que estamos refiriendo, pues el duque pide al monarca oficios y mercedes para sus criados con esta intención.

Entre los caballeros que mantenian una relación de clientela política

61 Becelpo, Isabel, y Cordoba de la Llave, Ricardo, ob. cit., pág. 334.

6? Este personaje habia participado también en la guerra de Granada como capitán de jinetes y de hombres de armas. AGS. Contaduria del Suelo, legajo 38. Citado por LADERO Quesada, Miguel Ángel, en Castilla y la conquista del Reino de Granada. Granada 1987, pág. 266 .

63 Véase nota 60.

${ }^{64}$ Gerbet, Marie Claude, ob. cit., págs. 152-153

6s Ibidem, pág. 153. 
con el duque aparece Sancho Martinez de Leiva, miembro de la casa de Leiva cuyo patrimonio se situaba también en Palencia. Con esta familia algunos Manrique habian tenido ciertos pleitos, ya que compartian el señorio de ciertas villas, como sucedió con Ezcaray, aunque al final se solucionaron "cordiaimente», y los señores de Leiva les vendieron su parte. Isabel Beceiro ha destacado como en algunas comarcas donde la impiantación de un señorio contribuia a la caída de la pequeña y mediana nobleza de la zona, algunos miembros de estos grupos se integraban en la casa del magnate como medio de asegurar su subsistencia y mantener estable un cierto estatus, tendencia que se acentuó con el triunfo desde comienzos del siglo $x v$ de los acostamientos, sueldos de oficiales y otras remuneraciones. En este sentido, dicha autora pone también de relieve que curiosamente algunos señores locales, como los Mendaña y Losada, entre otros, que vendieron sus aldeas y propiedades al tercer y cuarto Conde de Benavente, aparecian después como hombres de confianza de estos magnates, lo que la induce a pensar que lo importante no era el precio de la venta, sino la relación ulterior establecida, y que dichas ventas tenian fundamentalmente cel sentido de sellar y anudar esa vinculación» ${ }^{66}$. Estas interesantes observaciones pueden aplicarse al caso de los señores de Leiva y los Duques de Nájera.

Asimismo, Antonio Manrique ruega al monarca que confirme a Lope Garcia de Salazar los oficios y mercedes que tenía su padre Ochoa de Salazar, preboste de Portugalete, ya fallecido. El linaje de los Salazar mantenía desde hacia tiempo estrechos lazos con el primer duque. Otros deudos de la casa de Nájera que se relacionan son Tristán de Leguizano, los Alcaldes Garcia Fernández de la Mota, Luis de Barahona -que suponemos era hijo o familiar de Alonso, servidor del primer duque-, y por último, Gómez González de Buitrón, señor de Buitrón, Móxica y del valle de Aramayona. Este personaje fue un activo colaborador de Pedro Manrique, pero cuando éste fue sometido por Fernando el Católico a su vuelta a Castilla, prestó inmediato pleito-homenaje al monarca y se excusó diciendo que toda la mala información que hubiera recibido sobre él era falsa y que pensaba servirle fielmente ${ }^{67}$. Los Duques de Nájera extendieron sus lazos de clientela entre los señores de las provincias de Álava, Vizcaya y Guipúzcoa ${ }^{68}$, sobre las que ejercieron una gran influencia,

${ }^{66}$ Beceiro, Isabel, y Córdoba de la Llave, Ricardo, ob. cit., págs. 340-341.

67 Pleito-homenaje dado en Burgos, el 7 de diciembre de 1507, en manos de Bernardo de Rojas, Marqués de Denia. Biblioteca Nacional de Madrid. Manuscrito n. ${ }^{\circ} 17.475$, fols. 317 y ss.

68 En algunos albalaes hay noticias sobre diversos pagos que hizo el Duque de Nájera a gentes de Álava. AGS. Cámara de Castilla. Personas, legajo 19. Su hijo Antonio Manrique 
como lo demuestra su vinculación con la familia de los Salazar, o con el mencionado Gómez González de Buitrón uno de los caballeros más poderosos de las citadas provincias, al ser cabeza del bando de los oñecinos, quienes como vimos prestaron su colaboración al Duque de Nájera cuando intentó resistir por las armas.

No conocemos, sin embargo, la relación que con el mencionado duque tuvieron Mosén Miguel de Velázquez, para quien Antonio Manrique pedia el oficio de protonotario de Aragón, como lo tenia hasta el momento, y de Juan Gallo de Andrada para quien solicitaba el cargo de Teniente de Cataluña, oficio del que dice «que es de poca cantidad», pero todo hace sospechar que su conexión estuviese en el parentesco con algunos nobles aragoneses. Tampoco da los nombres de dos personas para las que demandaba la contaduria y la notaría de las Órdenes de Calatrava y Alcántara. Tan solo requiere al monarca que le haga «merçed dellas para dos ombres de bien que han mucho despues que el rey don Felipe falleçio en seguir el serbiçio de su alteza y han estado con el Duque mi padre en todas las cosas que por el han pasado después que el rey don Felipe falleçio".

Para terminar, otros personajes mencionados que colaboraron con Pedro Manrique para los que su hijo pide gratificación son: el Adelantado Mayor de Castilla, el Conde de Salvatierra, el Conde de Castro, el Mariscal de Frómista, Álvaro Hurtado de Mendoza y un tal Sarmiento, del que refiere que le habían quitado una Capitanía que tenía por la Reina Isabel y suplica que le sea devuelta. Es de suponer que con estos individuos habia establecido el duque ciertas confederaciones o alianzas politicas.

En definitiva, como puede verse, Pedro Manrique arrastró a un gran número de familiares, deudos y parientes en su determinación política de oponerse al rey Fernando. El contar con una gran clientela politico-militar, fundamentada en las relaciones de parentesco real o ficticio, era una importante base de apoyo para el logro de los objetivos politicos. Todos los que componian la mencionada clientela vinculaban su fortuna al éxito del jefe politico o del señor. Su caida en desgracia también les afectaba, como lo señala continuamente Antonio Manrique cuando habla de los muchos agravios y daños que todos los deudos, parientes y criados de la casa de Nájera han recibido.

explica también en el Memorial que a la muerte de Fernando el Católico, él escribió al Condado de Vizcaya y a Guipúzcoa para que se mantuviesen en la paz y sosiego. Memorial... AGS. Diversos de Castilla, leg. $39, n .{ }^{\circ} 32$. 
Por otra parte, las peticiones que hace el II Duque de Nájera, Antonio Manrique en el Memorial, demuestran el interés que tenía la nobleza por hacerse pagar sus servicios, su fidelidad al monarca, y llama la atención la importancia que en general tienen los cargos y oficios como recompensa. De la lectura del citado Memorial se desprende también lo costoso que era para el jefe de un linaje, en este caso el Duque de Nájera, "mantener" en un sentido amplio tanto a familiares, como a deudos y vasallos. Las elevadas tasas de natalidad en la nobleza suponian una carga cada vez más pesada para el cabeza de familia, que tenia que ocuparse de buscar un porvenir a los que dependían de él. La coyuntura de paz que existia en Castilla desde la llegada al trono de los Reyes Católicos habia cerrado algunas de las que habian sido importantes vías de promoción y de mantenimiento para los nobles, la lucha politica y la guerra, especialmente una vez que se concluyó la conquista de Granada. Parece claro que la nobleza tenía que adaptarse a los nuevos tiempos y que su supervivencia, sobre todo en los estratos más inferiores del estamento nobiliario, estaba vinculada a su integración en los aparatos politico-administrativos de la Corona, que en lo que al grupo noble se refiere, eran esencialmente, la corte y los órganos militares, entre los que incluimos las tenencias de fortalezas, como lo demuestran las continuas referencias que a este tipo de cargos hace el Duque de Nájera. Las quitaciones que se devengaban por el desempeño de ciertos oficios eran para la nobleza un ingreso seguro, más o menos importante dependiendo del nivel social y econórnico de cada noble.

\section{IDEOLOGIA Y ACTUACIÓN POLITICA}

Como acabamos de referir, Pedro Manrique, I Duque de Nájera, contó con importantes apoyos familiares y una amplia clientela política para oponerse a la gobernación de Fernando el Católico. Además gozaba de un rico patrimonio, varias fortalezas y un estado señorial en una posición geográfica excelente por su ubicación fronteriza. Sin embargo, todas opción política tenia unas causas ideológicas que la justificaban. Mucho se ha discutido sobre si el comportamiento político de la alta nobleza respondia o no a una ideología concreta, y en líneas generales se acepta que la teoria política no determinó las actuaciones nobiliarias ${ }^{69}$, sino que

${ }^{69}$ Quintanilla Raso, M. ${ }^{*}$ Concepción, "La nobleza en la historia política castellana en la segunda mitad del siglo xv. Bases de poder y pautas de comportamiento", Congresso internacional Bartolomeu Dias e a sua época, Actas. Volume 1. Porto 1989, págs. 198-199. 
fue utilizada por la nobleza para justificar ciertas posturas politicas que tenian como principal finalidad incrementar su poder y riqueza. No obstante, el que la nobleza recurriera a principios de teoria politica ${ }^{70}$ para legitimar su modo de actuar, requiere para algunos autores ciertas reflexiones, ya que sus puntos de vista mostraron en algunas ocasiones «por encima de lo coyuntural y accesorio, curiosas y sospechosas unanimidades y coincidencias" en sus propuestas básicas y en sus actuaciones ${ }^{71}$. Asi el profesor Nieto Soria ha resaltado que los nobles apelaron durante su enfrentamiento con la monarquia a diversos puntos de referencia de indudable valor ideológico-político para dar legitimidad a sus reivindicaciones ${ }^{72}$.

Durante la crisis sucesoria de comienzos del siglo xvI, la nobleza, de nuevo en un primer plano, volvió a dar claras muestras de que su intención -aunque oculta bajo ciertos argumentos politicos-era sacar el máximo rendimiento político y económico a la critica coyuntura, y así lo expresaron los contemporáneos de la época, como es el caso de Pedro Mártir de Angleria, quien en una de sus célebres cartas cita que la opinión de los nobles era «que sus antepasados por este camino reunieron y aumentaron sus patrimonios, afirmando que siempre hay ganancia cuando muchos andan desacordes acerca del mando... ${ }^{73}$. El general resentimiento por la progresiva pérdida de protagonismo político y la añoranza de los tiempos pasados, se unieron a los motivos particulares de descontento que tenian algunos nobles ${ }^{74}$, quiénes ante las promesas de recompensas por parte de Felipe del Hermoso ${ }^{75}$ vieron en él la candi-

\footnotetext{
10 Nieto Soria, José Manuel, en su obra Fundamentos ideológicos del poder real en Castilla (siglos xili-xvi). Madrid 1988, págs. 173-175.

1 TorRes Sanz, David, "Teoria y práctica de la acción de gobierno en el mundo medieval castellano-leonés", Historia. Instituciones. Documentos, 12. Sevilla 1985, pág. 52.

" Véase Nieto Soria, José Nlanuel, ob. cit., págs. 173-175.

13 Martir de Angleria, Pedro, 19 de noviembre de 1504, t. 1, pág. 58. En una carta Gutiérrez Gómez de Fuensalida, embajador del rey en Flandes, narraba a Fernando como don Juan Manuel, señor de Belmonte y consejero de Felipe el Hermoso, se dedicaba a decir que "en los tiempos de paz pocos son los que ganan, y en los tiempos rebueltos se hazen los ombres...", Correspondencia de Gómez de Fuensalida, embajador en Alemania, Flandes e Inglaterra (1496-1509). Madrid, Ed. Duque de Berwick y de Alba, 1907, pág. 322.

${ }_{74}$ Asi, por ejemplo, el Duque de Medinasidonia queria recobrar la fortaleza de Gibraltar que se había visto obligado a entregar a la Corona en 1502; el Marqués de Villena deseaba recuperar el señorio de Villena y Almansa; el Duque de Béjar ansiaba conseguir Plasencia, etc. Véase, Doussinague, José M. ${ }^{a}$, Fernando el Católico y Germana de Foix. Un matrimonio por razón de Estado. Madrid 1944, pág. 46.

${ }^{75}$ El Archiduque mantuvo estrecho contacto con casi todos los grandes nobles: Diego Pacheco, Marqués de Villena, Alonso Pimentel, Conde de Benavente, Hurtado de Mendoza, Duque del Infantado, Juan de Guzmán, Duque de Medinasidonia, Pedro Fernández, Marqués de Priego, Juan Téllez Girón, Conde de Urueña y otros de menor estado, que habian escrito
} 
datura politica idónea. El Archiduque representaba un modelo politico más acorde con sus intereses, frente al esquema autoritario impuesto por los Reyes Católicos, que tendria en Fernando su continuador. No extraña por tanto la rapidez con la que se desarrolló el bando nobiliario antifernandino, que tomó como principal argumento politico para oponerse al rey Católico, los derechos a gobernar de Juana y Felipe.

Recientemente se ha demostrado que el rechazo de la nobleza a que Fernando asumiese el gobierno no era nuevo, sino que ya se habia puesto de manifiesto algunos años antes. En el texto para la convocatoria de las Cortes de 1499, reunidas para jurar heredero al Principe Miguel, se indicaba la obligación de aceptar las cláusulas testamentarias de Isabel que regularian la futura minoria del titular de la Corona. Sin mencionarlo era obvio que la gobernación recaeria en Fernando el Católico. El estamento nobiliario, que con su absentismo a la reunión demostró su oposición a que Fernando tomase el poder efectivo en Castilla, hubo de ser obligado a acatar por escrito todo lo acordado en las Cortes, ya que, según se ha dicho, los nobles temian la consagración del hegemonismo aragonés en la política castellana ${ }^{76}$. Por otra parte la adhesión nobiliaria a Felipe el Hermoso quedó patente tres años después, cuando la nobleza acudió unánimemente a las Cortes de 1502, tras la muerte del Príncipe Miguel, a jurarles a él y a su esposa doña Juana como herederos ${ }^{77}$.

El Duque de Nájera, como destacado miembro del estamento nobiliario recurrió a diversos argumentos políticos que justificasen su rechazo a la gobernación de Fernando y encubriesen sus verdaderos motivos - la ambición política y económica-, aunque fue el matrimonio del monarca con Germana de Foix, sobrina de Luis XII de Francia, el principal. Este erlace fue pactado por Fernando, ante el cariz que habian ido tomando los acontecimientos, para contrarrestar las intrigas politicas de su yerno Felipe el Hermoso tanto dentro como fuera de Castilla, y ha sido valorado por la historiografía desde muy diferentes ópticas, ya que esta «maniobra de gran estilo" ${ }^{78}$, si bien le permitió contar con el apoyo del monarca

al Archiduque para expresarle su adhesión. PADILLA, Lorenzo de, Crónica de Felipe el Hermoso, págs, 129-130. Sobre la correspondencia de Felipe el Hermoso con todos estos nobles véase CODOIN, t. VIII, págs. 275 y ss.

Carretero Zamora, Juan Manuel, ob. cit., pág. 194.

"Del alto clero asistieron 14 miembros, entre los que se encontraban personajes relevantes como Francisco Busleyden, obispo de Bensançon, administrador de Coria y preceptor de Felipe el Hermoso; 36 miembros de la nobleza territorial, más los representantes de la Administración Central y territorial. Ibidem, pág. 502. El Duque de Nájera asistió con su hijo Antonio Manrique. Estuvieron presentes también Alonso Manrique, obispo de Badajoz, y Luis Fernández Manrique, hijo del Marqués de Aguilar. RAH. 9/1784, fols. 195 y 196.

${ }^{18}$ Ladero Quesada, Miguel Ángel, ob. cit., pág. 295. 
francés ${ }^{79}$, no benefició en nada su inestable situación en el reino castellano. El matrimonio se convirtió en pieza clave de los razonamientos políticos del Duque de Nájera y sus seguidores, tanto antes como después del fallecimiento de Felipe el Hermoso, para rechazar la gobernación del monarca, por el problema politico, argumentaban, que se crearía si el rey tuviese algún descendiente, ya que se hizo circular el rumor de que en tal caso el monarca pretendia nombrarle sucesor en Castilla.

En el Memorial escrito por Antonio Manrique a Carlos I, ya varias veces citado, el II Duque de Nájera le explicaba que su padre tras la muerte de Felipe, "continuo lo que antes abia començado cumpliendo la lealtad y fidelidad que debia al rey nuestro señor, su hijo, porque la suçesion de su alteza fuese segura y no hubiese en ella impedimento, al qual se temia asy por estar casado el dicho señor rey de Aragon, ... y tambien por estar la dicha reyna preñada..." ${ }^{80}$. Antonio justificaba asi la actuación de su padre y de todos los que le habian apoyado, porque como ha comentado algún autor, las pretensiones nobiliarias no podian presentarse nunca como contrarias a los intereses regios, de ahi que siempre se tomase una determinada postura politica por el "bien del monarca" ${ }^{81}$, en este caso Carlos I, cuya legítima sucesión querian proteger. También Lorenzo de Padilla señala este mismo argumento cuando narra la negativa del Duque de Nájera a acudir a unas Cortes - a las que ningún otro cronista hace referencia- celebradas en Burgos, donde el Cardenal, el Condestable, el Almirante, la mayor parte de los grandes y prelados, y los procuradores del reino, juraron y recibieron por Gobernador a Fernando hasta que Carlos tuviese edad para asumir el gobierno. El Duque de Nájera, no asistió, dice el cronista, porque consideraba que atentaba contra los derechos del Príncipe heredero que el rey estuviera "casado con muger moza» 82.

Sin embargo, la fuerte oposición del Duque de Nájera a que Fernando asumiese el gobierno, aunque disfrazada con diversos argumentos politicos tenia mucho que ver con lo personal ${ }^{83}$. Por eso no resulta extraño que don Juan Manuel, señor de Belmonte, el agente y consejero de Felipe el Hermoso, que tanto influyó en el desarrollo del bando nobiliario anti-

${ }^{i 9}$ Sobre los pormenores de este enlace véase la obra de Doussinague, José M. ${ }^{a}$ citada en la nota 74.

(4) Memorial... AGS. Diversos de Castilla, leg. 39, n. 32.

' Nieto Soria, José Manuel, ob. cit., pág. 173.

82 Padilla, Lorenzo de, Crónica de Felipe el Hermoso, pág. 161

${ }^{83}$ Según relata algún cronista, que dice recoger la opinión de los contemporáneos, la oposición de Pedro Manrique a Fernando se basaba en «la enemistad que tenía el Condestable, yerno del Rey, por ciertos debates que siempre tenian». Bernaldez, Andrés, Crónica de los Reyes Católicos, pág. 731. 
Ideologia y parentesco: bases de la actuación política ...

fernandino hubiese logrado su pronta y rápida adhesión al Archiduque. El privado debia conocer bien el rencor que el Duque de Nájera y otros miembros del linaje Manrique guardaban al monarca, ya que se habian considerado agraviados por la falta de recompensas que habia tenido su servicio a los reyes durante el conflictivo proceso que les llevó al trono. Asi se deduce de la información que dio el embajador Guitiérrez Gómez de Fuensalida, entonces en Flandes, al rey Fernando en una de sus cartas escrita en enero de 1505, en la que referia: "Asymismo me dixeron oy personas ciertas y de creer que hablando don Juan en las cosas de Castilla, dixo: Hasta aqui la casa de los Manrriques ha estado abatyda; agora es su tiempo..." ${ }^{84}$.

Hay que tener en cuenta que una de las claves ideológicas del estamento nobiliario, se basaba en la obligación del rey de otorgar a los nobles, con máxima largueza, grandes dones y honores a cambio de los servicios prestados, especialmente como defensores del monarca y de la propia Corona. El rey desempeñaba, según se ha dicho, el papel de un ejecutor de la justicia distributiva que concede mercedes como premio a la fidelidad demostrada por los nobles, a quiénes parece que tuviera que pagar por su adhesión ${ }^{85}$. En el caso del Duque de Nájera contamos con diversos testimonios que permiten confirmar que esta idea estaba siempre presente en el pensamiento de la nobleza. En unas instrucciones que dio el duque, hacia 1512, a un criado suyo llamado Juan de Salinas, para que las entregase al rey Católico, leemos como Pedro Manrique, con un tono de amarga queja recuerda al rey sus muchos servicios que han quedado sin gratificar, concretamente le dice como:

"por hacer rey deste reino eché el alma en el infierno tomando al rey Enrique para Su Alteza lo que no le debiera tomar y destruyendo mi casa sobre sostener su servicio con solo mi gente, sin tener ninguna de Su alteza, ni aprovecharme de las rentas de su alteza como otros lo han hecho» ${ }^{86}$.

Resulta significativo que al cabo de tantos años, haya en la expresión del Duque, una cierta crítica a las actuaciones nobiliarias, entre ellas la suya propia, contra Enrique IV. Pedro Manrique dando saltos cronológicos, recuerda al rey también su colaboración en la guerra de Granada,

*4 Carta dada en Bruselas el 16 de enero de 1505. Correspondencia..., pág. 322

sb Nieto Soria, José Manuel, ob. cit., pág. 171.

RAH. Salazar. M-8, fols. 144-145. Publicado por Salazar y CaStro, Luis, Pruebas, págs 297 y ss 
en la de Portugal, y en la de Navarra. Con su arrogancia característica le increpa:

"Mas quiero acordar a Su Alteza que en todas las buenas guerrerias de sus capitanes, pocos a tenido su alteza que no ge los ayan desvaratado e echo mucho daño en su gente, y a mi, a dios gracias, ni moros, ni portugueses, ni navarros nunca me lo ficieron..." ${ }^{87}$.

No era, sin embargo, la primera vez que el Duque se quejaba del comportamiento de Fernando con él. Nada más llegar al trono los Reyes Católicos, siendo aún Conde de Treviño, dio ya muestras de su descontento. En un Memorial enviado al rey de Aragón, padre de Fernando el Católico le decía ${ }^{88}$ :

«... Que yo me quisiera excusar de dar enojo a su alteza con le hazer saber la forma que el Rey mi señor, su hijo, ha tenido conmigo creyendo se remediara; mas porque siempre se hace peor, tanto que va ya la cosa de tal qualidad como si yo fuese el mayor deservidor que en sus reinos tiene».

No conocemos la fecha exacta de esta queja del Conde, pero puede situarse por el contexto entre 1476 y 1479. Parece evidente que las relaciones de Pedro Manrique con Fernando nunca fueron excesivamente buenas, quizás porque el monarca llegó en algunos momentos a recelar de la fidelidad del Conde. De esos años tenemos constancia de la confusa actitud politica de Pedro Manrique por la información que dan los cronistas $^{89}$, y por la ratificación de un acuerdo en marzo de 1476 entre los Reyes Católicos y el Conde de Treviño sobre lo que le habian prometido por sus servicios cuatro años antes, posiblemente porque temian que abandonase su causa ${ }^{90}$.

En los alegatos de Pedro Manrique del Memorial de 1476, hay también un aspecto que merece ser destacado, igual que la nobleza queria ser

"I Ibidem

Bit Lo publicó Paz y Melia, Antonio, en El cronista Alonso de Palencia; su vida y sus obras: sus Décadas y las Crónicas contemporáneas; ilustraciones de las Décadas y notas varias. Madrid 1914, págs. 175-177.

véase Palencia, Alonso de, Crónica de Enrique IV, BAE. Madrid 1973, t. II, págs. 184 y ss., págs. 283 y ss., y $307-308$.

y En 1472 cuando el Conde de Treviño abandonó a Enrique IV y se incorporó al servicio de los Reyes, éstos le prometieron una serie de niercedes. Torrelaguna, 22 de diciembre de 1472. AGS. Patronato Real. Legajo 11, fols. 82. Este acuerdo fue ratificado el 2 de marzo de 1476. Ibidem, legajo 11 , fol. 81 . 
Ideología y parentesco: bases de la actuación política ...

gratificada por sus servicios, pensaba que el noble desleal al monarca debia ser castigado. El conde consideró muy injusto que los reyes no hubiesen condenado a los nobles que se habian rebelado contra ellos, aunque creia que la mayor injusticia era que no se hubiese recompensado a los que habian sido sus servidores, y así lo expresaba:

«... después que yo entré en este reino con el dicho Rey mi señor. nunca en al he gasto my tiempo syno en serville, y mientras su Señoria fue Principe, los unos tovimos en este reyno las faciendas en aventura por seguir e servir a su alteza, y otros muchos las acrecentaron deserviendole; y como quiera que después cuando su alteza reino fuimos todos juzgados por una ley, e aun quiza fue mas agraviada para algunos que esperabamos galardon” ${ }^{91}$.

En este sentido hay que recordar que, como se ha dicho, los Reyes Católicos evitaron seguir una política de vencedores y vencidos. Con un modelo de equilibrio los monarcas instauraron la paz sobre las bases de la concordia y los pactos, y lograron que por primera vez en muchos años, la monarquia se desligase del papel banderizo que habia tenido adjudicado durante tanto tiempo ${ }^{92}$. El tono de censura del conde demuestra que la nobleza no estuvo de acuerdo con este modelo politico, -aunque el particular desarrollo de los acoritecimientos la obligó a aceptar los hechos consumados-, y que en el fondo guardaba un resentimiento mayor de lo que a simple vista pudiera pensarse ${ }^{93}$. Sin duda sería interesante contar con más testimonios personales de la nobleza para saber hasta qué punto el estamento nobiliario se identificó con el programa político de los Reyes Católicos, aunque su colaboración en los acontecimientos de 1505 pone de manifiesto, en cierta medida, que no fue asi ${ }^{94}$

En suma, el noble quería siempre que se le recompensaran sus servicios, su mentalidad se basa en la contraprestación. La enorme lista de peticiones que hacia el II Duque de Nájera a Carlos V en su memorial ilustra sobradamente esta hipótesis. Esta forma de pensar pudo tener relación con la consideración del monarca como pariente mayor de toda la

Véase nota 88.

97 SuArez Fernandez, Luis, Nobleza y Monarquía. Puntos de vista sobre la Historia politica castallana del siglo xv, 2. edición. Valladolid 1975, pág. 259.

y3 No era el Duque de Nájera el único que se quejaba de las escasas recompensas por sus servicios, ZURITA, Jerónimo de, narra que el Conde de Urueña se lamentaba también de los agravios contra su persona, especialmente de como su colaboración en la guerra de Granada habia quedado sin gratificar, incluso habiendo muerto su hermano en ella. Los Cinco Libros..., Libro VII, pág. 119.

94 Suárez Fernandez, Luis, en Los Reyes Católicos. Fundamentos de la Monarquia. Madrid 1989, pág. 54, señala esta idea. 
alta nobleza, lo que le situaba por encima y al mismo tiempo al frente de todos los lazos de afinidad y clientela del grupo noble. Es conocido como los reyes en algunos documentos oficiales se dirigen a los duques, condes y marqueses con el tratamiento de tíos o primos, lo que en opinión de algún autor ${ }^{95}$, no era una sola fórmula de cortesia porque, aparte de que muchas veces habia vínculo de sangre, se expresaba asi que la alta nobleza colaboraba con la Corona en la administración de un patrimonio común. Si tenemos en cuenta esta idea, en el circulo nobiliario el pariente mayor tiene ciertas obligaciones con los que le sirven, y asi lo exige el estamento nobiliario.

Sin embargo, la nobleza, en este caso el duque como uno de sus principales representantes, no quería sólo recompensas económicas, sino también políticas, como se aprecia en el breve reinado de Felipe el Hermoso. El Duque de Nájera, como tantos otros nobles que habian apoyado a Felipe frente a las pretensiones de Fernando, recibió ciertas gratificaciones por sus servicıos cuando aquél comenzó a reinar, ya que el nuevo monarca le confirmó la merced de las alcabalas de la Merindad de Nájera, le dio el cargo de Capitán General de la Frontera de Navarra ${ }^{96}$, y al parecer también la tenencia de la ciudad de La Guardia ${ }^{97}$. No obstante, al igual que otros, se sintió defraudado, pues Felipe el Hermoso no le dio el protagonismo político que él esperaba. Por este motivo no es de extrañar que el duque y algunos destacados miembros de la nobleza como el Almirante o el Condestable ${ }^{98}$, se negaran a admitir que la Reina fuese declarada incapaz para gobernar y recluida, como deseaba el nuevo monarca, porque eso hubiera supuesto entregarle el poder absoluto, en un momento en el que habian surgido ya numerosas desconfianzas y recelos entre los grandes que no veian satisfechos por Felipe todos los pronósticos de medro politico que se habían hecho ${ }^{99}$.

Fue a la muerte de Felipe el Hermoso en Burgos el 25 de septiembre del mismo año de 1506 cuando se pusieron de manifiesto claramente los anhelos de poder político que tenía Pedro Manrique. Tras el gran descon-

95 Ladero Quesada, Miguel Angel, ob. cit., pág. 151.

96 Sólo cobró las alcabalas durante el año de 1505, aunque Fernando el Católico, en un albalá del 5 de febrero de 1508, ordena que se le acuda con ellas hasta el dia que fueron revocadas por doña Juana las mercedes concedidas por Felipe. Archivo General de Simancas. Mercedes y Privilegios. Legajo 78, fol. 11. En el cargo de Capitán General fue cesado Juan de Ribera. Zurita, Jerónimo de, Los Cinco Libros..., Libro VI, pág. 77.

"Memorial... AGS. Diversos de Castilla. Legajo 39, n. 32

98 ZuRITA, Jerónimo de, Los Cinco Libros..., Libro VI, fol. 73.

99 Ibidem, Libro VII, págs. 53,77 y 80 . 
cierto producido por el fallecimiento del monarca ${ }^{100}$, dicen algunos testimonios de la época, tomaron las riendas de todo el gobierno con el Arzobispo de Toledo, el Condestable y el Duque de Nájera, -quienes para la ocasión hubieron de olvidar sus diferencias-, y hasta que se reuniesen las Cortes, se intentó elaborar una concordia para regular el gobierno ${ }^{10}$. El Duque de Nájera dedicó todos sus esfuerzos a fortalecer el partido nobiliario que se oponia al regreso de Fernando a Castilla, y a defender su programa politico que consistía en el establecimiento de un gobierno de predominio nobiliario, pues pretendia que rigiesen Castilla unos "administradores" en nombre de Carlos, primogénito de la Reina, incapacitada claramente para gobernar. El duque deseaba que se estableciera una regencia en la que la nobleza tuviese el principal papel político, por lo que solicitó al Emperador que se proclamase Tutor del Principe don Carlos, increpándole para que nombrase ciertos "gobernadores" " ${ }^{102}$. Apoyaban el mencionado programa, don Juan Manuel, Señor de Belmonte, don Diego Pacheco, Marqués de Villena, el Duque de Béjar y el Conde de Benavente.

Pedro Manrique intentó defender este proyecto político incluso cuando Fernando, aún ausente de Castilla, le escribió, al igual que a los otros miembros de la nobleza que rechazaban su gobierno, para tratar de alcanzar con él un acuerdo. El monarca llegó a ofrecerle la confirmación de las alcabalas de Nájera, pero las exigencias del duque iban más lejos, pues seguia pretendiendo que el rey no impidiese a los nobles hacerse cargo de la persona del principe Carlos ${ }^{103}$, en el caso de que viniese a Castilla, que en el Consejo Secreto del rey hubiese siempre cinco grandes: el Almirante, el Condestable, el Marqués de Villena, el Duque de Alba, y él, quienes debian estar presentes «en todas las cosas, como so-

${ }^{100}$ Ibidem, págs. 81 y 82. ZuRita, Jerónimo de, narra como el dia antes de la muerte del Archiduque, previendo el final, se reunieron el Arzobispo de Toledo, el Condestable, el Almirante, el Duque del Infantado, el Duque de Nájera, el Marqués de Villena, el Conde de Benavente, el Duque de Alburquerque, el Duque de Béjar, el Conde de Castro, Andrea del Burgo y don Juan Manuel para elaborar una escritura que el citado autor transcribe, por la que se nombraba jueces a los cinco primeros y Andrea del Burgo. Entre los testigos aparecen Alonso Manrique, obispo de Badajoz y Garcia Manrique.

101 Del duque y el Condestable decia Pedro Mártir de Angieria que eran "cabecillas de los dos bandos españoles, que significan lo que entre los italianos las detestables, vesánicas e infernales denominaciones de Güelfos y Gibelinos". De los intentos de concordia dice este mismo autor «en vano están redactando ciertos estatutos, pues no hay ningún noble dispuesto a obedecer y a someterse a otro". Carta escrita en Burgos el 22 de noviembre de 1506, ob. cit., t. II, pág. 154

${ }_{102}$ ZuRita, Jerónimo de Los Cinco Libros..., Libro VII, págs. 93-94

${ }^{103}$ "... para que ellos le tuviessen y criassen", según narra ZuRIta, Jerónimo de, ob. cit., Libro VII, pág. 109 
lían estar en vida de la Reyna, los que al Rey parecia" ${ }^{104}$; y que en el Consejo de Justicia no hubiese personas sospechosas a los nobles. También pretendia que el Rey satisfaciese a todos los que habian seguido su opinión, entre los que señalaba a su pariente Alonso Manrique, obispo de Badajoz.

Tales peticiones fueron desoidas por el monarca, pero eran muy acordes con el estilo de actuación del estamento nobiliario en reinados anteriores, y por eso merece la pena comentarlas. El que la nobleza asumiese la regencia no era algo nuevo en Castilla, asi recuérdese cómo durante la minoría de edad de Juan II, algunos destacados nobles se habian hecho cargo del gobierno ${ }^{105}$. Menos novedoso aún era el que los nobles quisiesen estar presente en el Consejo, baste recordar las disputas nobiliarias que se sucedieron durante los reinados de Juan II y Enrique IV, para acceder y controlar el Consejo Real, ya que desde dicho organismo se dirigía e! gobierno del reino, y se distribuia la renta de la Corona ${ }^{106}$, en forma de tierras, tenencias, oficios o mercedes en dinero. Como es bien sabido, las reformas de los Reyes Católicos en la institución habian convertido al Consejo Real en un órgano del Estado controlado directamente por los monarcas ${ }^{107}$, en el que los nobles sólo podian participar a título honorífico, es decir, podian estar presentes en él, pero sin voz ni voto. Que esta consideración no satisfacia plenamente a la alta nobleza, relegada claramente del Consejo, lo confirma la petición del Duque de Nájera de que hubiese siempre cinco grandes en él.

En cuanto a la distinción que hace Pedro Manrique entre Consejo Secreto y Consejo de Justicia, ya en el reinado de Juan II, algunos testimonios parecian indicar la existencia de un doble consejo, uno de carácter público y composición mayoritaria de letrados, donde se trataban esencialmente las cuestiones judiciales, denominado "Consejo de la Justicia", y otro restringido o privado, llamado en ocasiones "Consejo Secreto", donde se trataban los negocios más importantes de la administración y gobierno, compuesto de personas muy calificadas por su condición

104 IDidem, Libro VII, pág. 109

${ }^{105}$ Asi, por ejemplo, cuando Fernando de Antequera partió para Aragón, nombró como regentes de Juan II a don Sancho de Rojas, Arzobispo de Toledo, al Almirante Alfonso Enriquez, al Condestable Ruy López Dávalos, y al Adelantado Pedro Manrique. Barrientos, Lope, Refundición de la Crónica del halconero, ed. Juan de Mata CARRIAzo. Madrid 1946. pág. 22

${ }^{106}$ Dios, Salustiano de, El Consejo Real de Castilla. Madrid 1982, pág. 105.

${ }^{107}$ Ibidem, pág. 151. 
nobiliaria ${ }^{108}$. Las referencias del duque parecen estar en consonancia con la mencionada duplicidad, porque cuando cita el Consejo Secreto, los cinco miembros que establece para su composición son altos nobles, y cuando se refiere al Consejo de Justicia, no especifica. Por otra parte si se tiene en cuenta que desde el reinado de los Reyes Católicos se inició un proceso de creación de nuevos consejos a tenor de las necesidades del estado, también podría pensarse que el Consejo secreto del que habla el duque fuese el origen del posterior Consejo de Estado en el que se integró especialmente la nobleza, y al que se le denominó con mucha frecuencia "Secreto", donde se trataban las cuestiones de mayor importancia para el reino ${ }^{109}$.

En suma, puede decirse que en las reivindicaciones políticas de Pedro Manrique habia grandes dosis de nostalgia del pasado, y un gran afán por recuperar el protagonismo político que el reinado de los Reyes Católicos habia eclipsado.

\section{REFLEXIONES FINALES}

Como puede observarse, a comienzos del siglo xvı las bases de la actuación política de la nobleza no habian cambiado mucho respecto a la centura anterior. Seguía siendo evidente que, como ha señalado $M .{ }^{a} \mathrm{C}$. Quintanilla, "el logro de los objetivos politicos era cuestión de fuerza, de recursos - lanzas, rentas, castillos, señorios, tropas privadas, apoyos exteriores, medios financieros, etc.-, más que de argumentaciones más o menos sólidas y bien fundamentadas" ${ }^{110}$. La derrota politica del Duque de Nájera demuestra también lo importante que era para la nobleza, de-

${ }^{108}$ No obstante la imprecisión de las fuentes impiden afirmar si se trataba realmente de dos Consejos, o de uno solo con duplicidad de reuniones o secciones, porque los grandes Ordenamientos legales sólo hacian referencia a un Consejo Real, al que además con frecuencia se le denominaba Consejo de Justicia. Ibidem, pág. 124.

${ }^{109}$ Así también lo ha señalado Salustiano de Dios porque el Consejo Real fue limitándose a las cuestiones de gobierno y especialmente de justicia, mientras que los asuntos de gracia, merced y estado de los que parecia encargarse el Consejo Secreto tuvieron unos órganos especificos, el futuro Consejo de la Cámara para los primeros, y el Consejo de Estado para los segundos. lbidem, págs. 127 y 175.

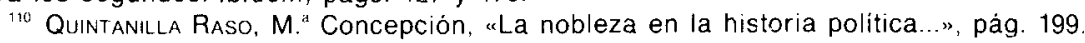


masiado voluble ${ }^{111}$ en sus planteamientos y en sus alianzas, mantenerse cohesionada, ya que en su unión radicaba su verdadera fuerza, un noble aislado no podia enfrentarse a una monarquía cada vez más potente. Esto lo sabia bien Pedro Manrique, que en una carta enviada al Duque del Infantado en 1510 le reprochaba que no se hubiese mantenido firme en su postura politica cuando fue necesario para ellos ${ }^{112}$, en clara referencia a los recientes sucesos políticos, lo mismo que muchos años antes, sí hacemos caso a Zurita, habia censurado al Condestable que por no haberse concertado con él cuando el rey Fernando comenzó a gobernar, "dexaron los dos de medrar, y otros muchos» ${ }^{113}$.

Por otra parte, los problemas internos de Castilla no se solucionaron tan rápida ni eficazmente como pudiera pensarse. En los años siguientes al regreso de Fernando destacados miembros de la nobleza, entre los que, claro está, se encontraba el Duque de Nájera, siguieron conspirando contra el monarca a pesar de los pleitos-homenajes que le habian prestado ${ }^{114}$. En 1508 hubo ciertos intentos de confederación por parte de algunos grandes castellanos, entre los que cabe destacar el Duque del infantado, e incluso a alguno de los fieles servidores del rey, como fue el caso del Condestable, quien al parecer estuvo a punto de concertar el matrimonio de su hermana doña Mencia con el Duque de Nájera ${ }^{115}$. La inestabilidad politica se prolongó durante 1509 según refieren los cronistas, para ir decayendo progresivamente, sobre todo a raiz de la concordia entre Fernando el Católico y el Emperador Maximiliano sobre el gobierno del reino castellano.

$" 11$ Aunque los principales nobles habian establecido ciertos acuerdos, como los de Grijota, por los que se comprometian a no admitir al Rey en Castilla hasta que no se hubiesen satisfecho las demandas de todos, - por ejemplo el Almirante queria que se le concediese el Almirantazgo del Reino de Granada con los derechos que llevaba en el obispado de Cádiz y en el Arzobispado de Sevilla, y la tenencia de Simancas; el Marqués de Benavente, las ferias de Villaión, etc.-, poco a poco comenzaron las deserciones y el movimiento se fue debilitando con la vuelta al servicio del Rey de los principales implicados, a cambio de ciertas recompensas. Primero se reconcilió el Conde de Benavente, después el Duque de Béjar, y más tarde el Marqués de Villena.

Véase Zurita, Jerónimo de, Los Cinco Libros..., Libro VII, pág. 110.

112 Archivo Histórico Nacional. Osuna, legajo 2288-2. Fol. 22.

11 ZuRita, Jerónimo de, Los Cinco Libros..., Libro VI, pág. 13.

${ }^{114}$ Desde 1507 hasta 1509 Fernando recibe diversos pleitos homenajes de la nobleza y de ciertos alcaides de fortalezas, como puede verse en las copias recogidas en un libro existente en la Biblioteca Nacional de Madrid, Manuscritos, n." 17.475, fols. 292 y ss.

${ }^{115}$ ZuRIta, Jerónimo de, Los Cinco Libros..., Libro VIII, págs. 173 y ss. 